\title{
Nordisk Policy-sammendrag
}

Nordic policymaking on sustainable consumption with accessible knowledge and by dispelling myths that thwart sustainability"

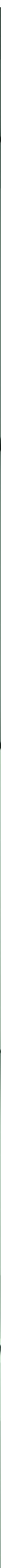



4 norden 



\section{Nordisk Policy-sammendrag}

Erfaringer fra den nordiske unders $\varnothing$ gelse "improving Nordic policymaking on sustainable consumption with accessible knowledge and by dispelling myths that thwart sustainability"

Oksana Mont, Lund Universitet, Sverige

Kate Power, Copenhagen Resource Institute, Danmark

Eva Heiskanen, National Consumer Research Centre, Finland

Helka Kuusi, National Consumer Research Centre, Finland 
Nordisk Policy-sammendrag

Erfaringer fra den nordiske undersøgelse "improving Nordic policymaking on sustainable consumption with accessible knowledge and by dis-pelling myths that thwart sustainability" Oksana Mont, Lund University, Sverige

Kate Power, Copenhagen Resource Institute, Danmark

Eva Heiskanen, National Consumer Research Centre, Finland

Helka Kuusi, National Consumer Research Centre, Finland

ISBN 978-92-893-2613-1

http://dx.doi.org/10.6027/

TemaNord 2013:567

(C) Nordisk Ministerråd 2013

Layout: Hanne Lebech

Omslagsfoto: ImageSelect

Tryk: Rosendahls-Schultz Grafisk

Oplag: 46

Printed in Denmark

Denne rapport er udgivet med finansiel støtte fra Nordisk Ministerråd. Indholdet i rapporten afspejler dog ikke nødvendigvis Nordisk Ministerråds synspunkter, meninger, holdninger eller anbefalinger.

www.norden.org/da/publikationer

\section{Det nordiske samarbejde}

Det nordiske samarbejde er en af verdens mest omfattende regionale samarbejdsformer. Samarbejdet omfatter Danmark, Finland, Island, Norge og Sverige samt Færøerne, Grønland og Åland.

Det nordiske samarbejde er både politisk, økonomisk og kulturelt forankret, og er en vigtig medspiller i det europæiske og internationale samarbejde. Det nordiske fællesskab arbejder for et stærkt Norden i et stærkt Europa.

Det nordiske samarbejde ønsker at styrke nordiske og regionale interesser og værdier i en global omverden. Fælles værdier landene imellem er med til at styrke Nordens position som en af verdens mest innovative og konkurrencedygtige regioner.

Nordisk Ministerråd

Ved Stranden 18

1061 København $\mathrm{K}$

Telefon (+45) 33960200

www.norden.org 


\section{Indhold}

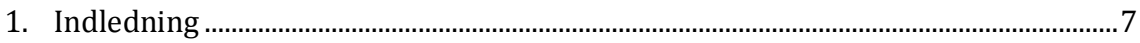

$1.1 \quad$ Målet med undersøgelsen...................................................................................

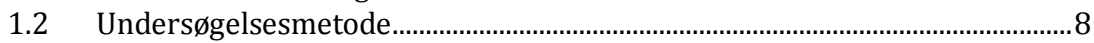

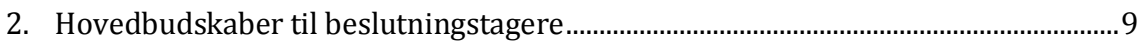

3. Hovederfaringer med myter ....................................................................................... 11

3.1 Myte 1: Grønt forbrug er løsningen ............................................................ 11

3.2 Myte 2: Forbrugerne skal føre an i overgangen til et bæredygtigt

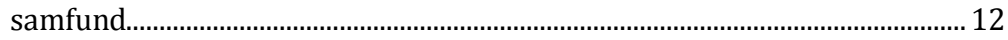

3.3 Myte 3: Hvis alle yder en lille indsats, opnår vi store resultater .................. 13

3.4 Myte 4: Små og lette miljøtiltag vil medføre en spillover effekt og skabe større forandringer .................................................................................... 14

3.5 Myte 5: Mere information medfører bæredygtig adfærd............................... 14

3.6 Myte 6: Vejen til bæredygtig adfærd er at appellere til menneskers egeninteresse .................................................................................................... 15

3.7 Myte 7: Bæredygtig livstil betyder, "at man lever som huleboer" ............... 16

3.8 Myte 8: Mennesker bliver lykkeligere, hvis de tjener flere penge og forøger deres materielle forbrugsniveau............................................................ 17

3.9 Myte 9: Privat ejerskab af alle former for produkter er ønskeligt deling er ikke............................................................................................................. 18

3.10 Myte 10: Forbrugerpolitik er for kontroversiel til at blive accepteret af offentligheden .......................................................................... 19

4. Hovederfaringer med vidensformidling................................................................ 21

4.1 Sådan bruges forskningsresultater i politikformuleringen............................ 21

4.2 Tilgængeligheden af tilstrækkelig forskning med henblik på politikformulering inden for bæredygtigt forbrug........................................ 22

4.3 Evidensbaseret politik inden for bæredygtigt forbrug ................................... 23

4.4 Hindringer i forhold til anvendelsen af viden og idéer med henblik

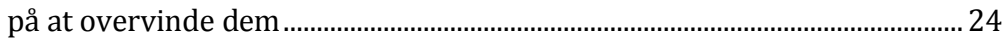

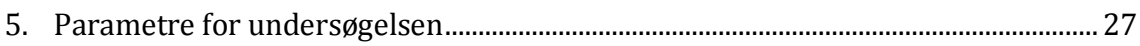

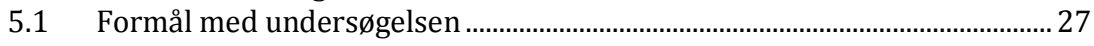

5.2 Resultaterne af undersøgelsen ................................................................... 28

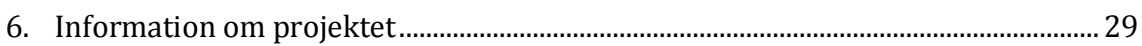





\section{Indledning}

På trods af 20 års politikformulering om bæredygtigt forbrug (UNCED 1992) fortsætter det materielle forbrug og de miljømæssige konsekvenser med at stige i de nordiske lande og Europa. De nordiske lande har en ambition om at være førende indenfor bæredygtig samfundsudvikling. Det er derfor vigtigt at fremme og gøre det let af leve og forbruge bæredygtigt gennem en effektiv forbrugerpolitik, der kan sikre udnyttelsen af ressourcer og reducere de miljømæssige konsekvenser. Det er dog klart, at den nuværende forbrugerpolitik ikke er så effektiv, som den kunne være.

Der er identificeret en række grunde til dette, lige fra forbrugernes selvbestemmelsesret, manglen på politiske instrumenter, og til manglen på politisk mod i forhold til at involvere sig i forbrugerspørgsmål. Desuden viser forskningen, at evidens fra adfærds- og socialvidenskaberne ikke rutinemæssigt inddrages i politikformuleringen - selv om en stor del af de miljømæssige konsekvenser af vores forbrug afhænger af forbrugeradfærd og vaner.

Som følge heraf hersker der nogle vedvarende misforståelser - myter - om forbrugeradfærd i den almene forståelse af bæredygtigt forbrug, især i de politiske cirkler. Fastholdelsen af disse myter tilskynder beslutningstagerne til at fokusere på teknologisk innovation for at opnå produkteffektivitet. Herved får social innovation, nye alternative modeller for værdiskabelse og normer for et tilstrækkeligt eller rimeligt forbrug ikke den fornødne opmærksomhed. Disse misforståelser afholder beslutningstagerne fra at erkende forbrugets kompleksitet i det virkelige liv og se begrænsningerne i de halve forholdsregler, som mange politiske tiltag inden for bæredygtigt forbrug anbefaler. Myterne forhindrer beslutningstagerne i på en effektiv måde at tage fat på de udfordringer, som er knyttet til forbrug og bæredygtig samfundsudvikling.

\subsection{Målet med undersøgelsen}

Målet med denne undersøgelse er at eliminere de myter, der forhindrer bæredygtig samfundsudvikling ved at fremlægge den eksisterende evidens om forbrugeradfærd, og dermed fremme udviklingen af effektive politiske tiltag inden for bæredygtigt forbrug i de nordiske lande. 


\subsection{Undersøgelsesmetode}

For at eliminere myterne om forbrugeradfærd er undersøgelsen baseret på solid international forskning i forbrugeradfærd indenfor psykologi, sociologi, adfærdsøkonomi, politik og antropologi. Denne viden har ikke nået flertallet af de beslutningstagere, som arbejder med spørgsmål knyttet til bæredygtigt forbrug. Undersøgelsen gør brug af en tilgang, som er baseret på formidling af viden. Udveksling og overførsel af den omfattende akademiske og praktiske tværfaglige viden sker mellem forskere, beslutningstagere og praktikere i et format som er lettilgængeligt og let at bruge for at fremme og faciliterer anvendelsen af den eksisterende viden i den reelle politik. 


\section{Hovedbudskaber til beslutningstagere}

Det er urealistisk at forvente, at omstillingen til et bæredygtigt samfund vil ske på baggrund af de nuværende politiske strategier inden for bæredygtigt forbrug. Der er behov for betydelige ændringer, og forskningen som præsenteres i denne undersøgelse viser, at beslutningstagerne har en overflod af muligheder for at skabe positive ændringer og udnytte synergier mellem en række strategier og værktøjer.

Vi lever i et forbrugersamfund: Samfundets strukturer fremmer forbrugsmønstre, som mennesker i Norden anser for at være normale, men som reelt ikke er bæredygtige. På den anden side møder borgere, som forsøger at foretage væsentlige livstilsændringer, uovervindelige sociokulturelle forhindringer i forhold til en bæredygtig hverdag. Dette understreger behovet for, at regeringerne tager føringen, når det gælder overgangen til en bæredygtighedskultur.

Regeringerne skal tage føringen, når det gælder overgangen til bæredygtig livsstil ved at skabe de samfundsstrukturer som skal til for at gøre bæredygtig levevis til en norm. Innovation inden for teknologi, infrastruktur, lovgivning, prissætning, markedsføring og nye sociale normer kan kombineres og dermed skabe en bæredygtig valg-arkitektur for forbrugerne.

Lovgivning udgør ofte det mest effektive politiske tiltag når det gælder ændring af forbrugsmønstre. Selv om lovgivning kan være mere udfordrende at gennemføre, findes en dokumentation i form af praktiske teknikker med henblik på en succesfuld implementering af stærkere politiske tiltag. Lovgivning er ofte mere effektiv, når den bruges i kombination med andre politiske instrumenter, eksempelvis økonomiske og informations værktøjer i såkaldte politiske pakker.

Etablering af positive sociale normer er central med henblik på at indlemme bæredygtige praksisser i hverdagslivet og at øge den offentlige accept af en stærkere forbrugerpolitik. Selv politiske tiltag som er baseret på tvang og forbud, og som kræver betydelige livsstilsændringer (fx at skifte fra privatbilisme til offentlig transport), kan opnå en højere grad af offentlig accept, hvis tiltagene præsenteres på en hensigtsmæssig måde. Forbrugerpolitiske tiltag kan styrke de sociale normer når det 
gælder miljø- og samfundsmæssig nytte ved at etablere sikre, komfortable og billige bæredygtige alternativer til forbrugeradfærd, der ikke er bæredygtig.

Der er behov for et politisk fokus på at fremme en bæredygtig livsstil på forbrugsområder, som har store konsekvenser på miljøet (fx flyrejser, spisning af kød og mælkeprodukter og kørsel i egen bil). Der må ske en ændring til forbrugsområder, som har færre konsekvenser for miljøet (fx spisning af vegetarisk mad, brug af offentlig transport, og tilvalg af lokale fritids- og kulturaktiviteter og personlig udvikling).

Der er behov for en langt mere nuanceret diskussion af vejene til velfærd end den fremherskende holdning i øjeblikket, hvis vi skal forstå og støtte menneskers drift med henblik på at blive lykkeligere og sundere. Det kan være nyttigt at formulere en bredere vision for velfærd, som indeholder samfundsgavnlige værdier, såsom bæredygtige samfund, et rimeligt og bæredygtigt ressourceforbrug, sundhed, uddannelse og personlig udvikling, fred og stabilitet, miljømæssig og social retfærdighed og andre mere grundlæggende spørgsmål som indirekte påvirker de enkelte borgere og deres familier. Der skal desuden udvikles nye mål for samfundsmæssig velstand med henblik på at støtte og fremme bæredygtig levevis. 


\section{Hovederfaringer med myter}

\subsection{Myte 1: Grønt forbrug er løsningen}

Grønt forbrug er en, men ikke den eneste strategi med henblik på at reducere ressourceforbruget og de miljømæssige konsekvenser som følge af forbrug.

Fakta: Grønt forbrug er en vigtig - men begrænset - strategi med fokus på at forbedre effektiviteten i produktionsprocesserne og at udvikle og sælge produkter som er miljømæssigt og socialt forsvarlige.

Udfordringer: Det er afgørende også i fremtiden at forøge effektiviteten i fremstillingen af forbrugerprodukter, men det er ikke tilstrækkeligt: Selv produktion og forbrug af, "grønne" produkter har konsekvenser for miljøet. Forbruget er stigende og ikke bæredygtige forbrugsmønstre udvikler sig hurtigere end de opnåede forbedringer i forskellige stadier af produktionen og produktudviklingen. Således hjælper grønt forbrug os med at bremse miljøproblemerne, men kan ikke i sig selv forebygge eller forhindre dem.

Myten fremmer det fejlagtigt optimistiske synspunkt, at teknologiske løsninger er tilstrækkelige for at opnå et bæredygtigt samfund. Den fjerner fokus fra behovet for at tage fat på udfordrende spørgsmål, eksempelvis den fremherskende forbrugerkultur og materialismen, som er tæt forbundet med udnyttelse af ressourcer og konsekvenser for miljøet.

Virkninger: Strategier for bæredygtigt forbrug og bæredygtig livsstil skal supplere effektivitetsstrategier, som eksempelvis kunne bestå af udskiftning af produkter med forbrug af tjenester, eller at deles om produkter i stedet for at eje dem. At bruge den uudnyttede varekapacitet $\mathrm{i}$ stedet for at kassere denne og fremme en kreativ kultur, når det gælder genbrug og reparation af forbrugerprodukter. 


\subsection{Myte 2: Forbrugerne skal føre an i overgangen til et bæredygtigt samfund}

Der er en grænse for, hvad man kan opnå via ændringer i den individuelle adfærd. Der er behov for systemiske forandringer i de fremherskende økonomiske institutioner og forretningsmodeller, lovgivningen og infrastrukturen. Regeringerne skal føre an i overgangen til et bæredygtigt samfund. Individerne, virksomhederne og civilsamfundet har andre vigtige roller at spille.

Fakta: Forbrugerne har selv en del af ansvaret for de miljøkonsekvenser deres forbrug og livsstil, ikke mindst fordi husholdningerne står for 40 pct. af de samlede miljøbelastninger i samfundet. Det er imidlertid regeringerne som kan igangsætte de omfattende ændringer, når det gælder kultur, forbrug og produktionsmønstre.

Udfordringer: Der eksisterer en fejlagtig opfattelse af, at forbrugerne styrer markederne, og at virksomhederne blot reagerer på efterspørgslen. Både virksomheder og beslutningstagere er valgarkitekter, som definerer hvilke valgmuligheder forbrugerne har. De dominerende samfundsmæssige værdier, praksisser og sociale normer skabes politisk, eksempelvis via lovgivningen, infrastrukturer, prissætningsmekanismerne og uddannelsessystemer

Virkninger: Denne undersøgelse viser, at adskillige interessenter, herunder virksomheder og forbrugere, opfordrer regeringerne og beslutningstagerne til at udvise lederskab. Regeringerne er de mest betydende aktører for gennemførsel af de store ændringer i vores forbrugskultur. Borgerne, virksomhederne og civilsamfundet har andre vigtige roller at spille.

Bæredygtig livsstil skal opfattes som en fundamental nødvendighed ikke blot som en valgmulighed, når man køber ind. I øjeblikket finder mennesker, der forsøger at leve bæredygtigt, det ofte vanskeligt at leve i opposition til de gældende normer og måder at gøre tingene på. Visse måder at leve på er "låst inde" af infrastrukturelle begrænsninger, prissætning og sociale konventioner. Politikformulering spiller en central rolle for at gøre en bæredygtig livsstil til den fremherskende norm i samfundet. Det er nødvendigt, at regeringerne påtager sig lederrollen med hensyn til at gøre bæredygtig livsstil mulig. 


\subsection{Myte 3: Hvis alle yder en lille indsats, opnår vi store resultater}

Alle bør bidrage til omstillingen til et bæredygtigt samfund, men der er brug for store forandringer.

Fakta: Små forandringer er et vigtigt udgangspunkt. Sloganet "hvis alle yder en lille indsats, opnår vi store resultater" understreger, at hver enkel borgers bidrag er værdifuldt og betydningsfuldt, og at alle andre også tager ansvar for deres adfærd og skaber forandringer. Små forandringer er vigtige, fordi mennesker har brug for at begynde et sted, føle sig som del af gruppen, og føle at de gør noget godt. Det er imidlertid en stor udfordring at vende udviklingen og etablere en ny social norm.

Udfordringer: Den største fejlopfattelse er, at små individuelle forandringer vil medføre betydelige resultater, idet summen af de små individuelle forandringer oftest kun medfører små samlede forbedringer. Et andet problem er udformningen af sloganet. Folk ved, at det ikke er alle "som tager deres del af ansvaret", og det afholder måske nogle fra at handle. De har ofte svært ved at se, hvordan små tiltag i husholdningerne kan hjælpe med at løse de globale miljøproblemer, hvilket fører til skepsis. Det kan også anspore til "gratister", hvis folk tror, at deres manglende handlinger ikke vil have nogen betydelig effekt for fællesskabet. I tilknytning til disse problemer forekommer to former for forbrugeradfærd, hvor betydningen af egne handlinger overfortolkes og tilskynder til øget forbrug. En adfærdsmæssig reboundeffekt finder sted, når folk mener, at deres små symbolske handlinger (fx genbrug af papir) retfærdiggør et fravær af handling på andre områder (fx at køre bil i stedet for at bruge offentlig transport). En økonomisk reboundeffekt finder sted, når folk sparer penge ( $\mathrm{fx}$ hvis de cykler i stedet for at køre bil) og bruger de sparede penge på aktiviteter som har store konsekvenser for miljøet (fx ferier til fjerne destinationer).

Virkninger: Små forandringer og massebevægelser gør en forskel, men det er afgørende at få frem, at der også er brug for store forandringer. Det er vigtigt med positiv opmuntring og at skabe et realistisk billede af omfanget af de nødvendige ændringer i omstilling til et bæredygtigt samfund.. Den borgerrettede kommunikation fra beslutningstagerne og civilsamfundet bør både lægge vægt på den relative vigtighed af de små forandringer, som den enkelte borger kan skabe i deres liv samt kommunikere de nødvendige, mere omfattende, ændringer, der er nødvendige i omstillingen til et bæredygtigt samfund og de muligheder borgerne har for at deltage i disse. 


\subsection{Myte 4: Små og lette miljøtiltag vil medføre en spillover effekt og skabe større forandringer}

Spillover effekter er kun sandsynlige mellem ensartede tiltag eller sammenhænge.

Fakta: Marketingteorien opfordrer os til at "begynde der, hvor mennesker befinder sig", fă dem til at bevæge sig i den rigtige retning med et let tiltag, som efterfølgende teoretisk set skulle gøre det lettere at tage det næste skridt inden for adfærdsændringen. Forskning viser, at positive spillover effekter oftest forekommer mellem ensartede tiltag, fx kan genbrug på arbejdspladsen fremme genbrug i hjemmet, eller køb af miljømærkede produkter kan medføre, at man også køber Fair Trade-produkter.

Udfordringer: Positive spillover effekter vil sandsynligvis ikke medføre større forandringer. Eksempelvis vil mindre tiltag, såsom genbrug, som regel ikke medføre de nødvendige større livsstilsændringer som $\mathrm{fx}$ at holde op med at køre i privat bil.

Virkninger: Spillover effekten kan være mere succesfuld, når mennesker vælger et lille tiltag og derefter opfatter sig selv som et miljøbevidst menneske. Dette kan fremmes ved at definere tiltagene som "positive for miljøet og samfundet" og ikke kun som "økonomisk besparende", og ved at fremme forandringer ved at iværksætte initiativer på samfundsniveau.

Mens det er vigtigt at opfordre mennesker til at ændre livsstil og starte med de tiltag der er lette at gøre selv for at reducere konsekvenserne for miljøet, er det helt afgørende at forstå, at man næppe kan forvente spillover effekter i form af signifikante livsstilsændringer. De signifikante livsstilsændringer skal stimuleres, støttes og fremmes via politiske tiltag inden for bæredygtig infrastruktur, prissætningsmekanismer samt gennem forbrugerinformation og budskaber fra markedsføring af bæredygtige varer og livsstil.

\subsection{Myte 5: Mere information medfører bæredygtig adfærd}

Information i sig selv vil som regel ikke medføre en adfærdsændring, men udgør en central del af den politiske pakke.

Fakta: At skabe opmærksomhed og informere er en nødvendig del af omstillingen til et bæredygtigt samfund. Information udgør en nyttig del af de politiske pakker, men i sig selv medfører information sjældent adfærdsændringer. 
Udfordringer: Mennesker handler ikke altid rationelt med henblik på at optimere nytteværdien af deres handlinger, og har ofte ikke adgang til den nødvendige information, tid, eller evner på andre måder ikke at tage stilling til alle fordele og ulemper i deres beslutninger og handlinger. Ud over information og opmærksomhed styres forbrugeradfærd af en række faktorer lige fra infrastruktur, institutioner, markedsføring og prissætning til følelser, vaner og normer. Adfærdsændringer vil sandsynligvis ikke forekomme, hvis de forskellige aktører på et område sender modstridende budskaber ( $\mathrm{fx}$ at man skal leve bæredygtigt, men også at vi skal "forbruge os ud af finanskrisen"). Det er endvidere en stor udfordring at fremme bæredygtig adfærd hos borgere gennem offentlige informationskampagner. Budskaber fra sådanne kampagner skal konkurrere med budskaber fra den kommercielle markedsføring og annoncering i medier, det offentlige rum og på internettet.

Virkninger: Bæredygtig adfærd skal fremmes af koordinerede budskaber, som ikke udelukkende spredes via informationstjenester, men som også udbredes gennem andre strategier, såsom øget tilgængelighed via infrastruktur, markedsføring, prissætning og samfundsmæssige institutioner. Der er et behov for at finde måder at kommunikere til borgere om miljømæssige problemer, så de stimuleres til handling fremfor at de modstiller sig handling.

Information kan have en effekt på adfærden, men sædvanligvis kun når der bruges stærke styringsinstrumenter på samme tid - især lovgivning og prissætning. Ofte kan man, på grund af gabet mellem holdninger og adfærd, opnå bedre resultater med kampagner, når mennesker får mulighed for at afprøve en ny og ændret adfærd i tillæg til den ydede information. Holdningsændringerne følger, når en ændret adfærd er etableret.

\subsection{Myte 6: Vejen til bæredygtig adfærd er at appellere til menneskers egeninteresse}

Der er behov for en balance mellem egeninteresse og værdier til gavn for samfundet for både at sikre de kortsigtede og langsigtede fordele.

Fakta: At appellere til egeninteressen ( $\mathrm{fx}$ ved at fremme miljøtiltag som en måde at spare penge på) er nogle gange effektivt på kort sigt og med henblik på specifikke adfærdsmønstre, som let kan knyttes til en forøgelse af den personlige nytte. Men at appellere til egeninteressen ud fra et materialistisk perspektiv kan utilsigtet forværre situationen på lang sigt.

Udfordringer: At sælge en bæredygtig livsstil via egeninteresse kan give bagslag, når der er behov for ændringer som ikke medfører nogen 
umiddelbar personlig nytte. Selv de fremtidige generationers interesser kan være vanskelige at beskytte i et samfund, som gennemfører miljøkampagner med budskaber om umiddelbare gevinster for den enkelte og værdsætter den hårde priskonkurrence på bekostning af miljøet og den sociale retfærdighed.

Virkninger: Beslutningstagere bør undgå at sende blandede meddelelser til borgerne, og de bør heller ikke lægge vægt på umiddelbare personlige gevinster, når det gælder samfundsmæssige værdier. Mennesker er tilbøjelige til at agere mere samfundsansvarligt, når der lægges vægt på frivillige initiativer og adfærd, der har socialværdi for andre medborgere og samfundet. Dette forøger både accepten af den førte politik i forhold til bæredygtigt forbrug samt effektiviteten af denne.

En mulig løsning er at udvide begrebet "egeninteresse", således at det også omfatter at bruge tid med familie og venner, sundhedsfremmende aktiviteter, samfundsmæssigt engagement etc. Selv social status kan knyttes til det at være en bevidst forbruger eller at leve enkelt på frivillig basis, i modsætning til en stressende og karriereorienteret livsstil med høje indtægter, høj levestandard og medfølgende store konsekvenser for miljøet. For at sikre et retfærdigt bæredygtigt samfund med stor social lighed, skal vi afstemme "Hvad får jeg ud af det?" med "Hvad får vi ud af det som fællesskab?".

\subsection{Myte 7: Bæredygtig livstil betyder, "at man lever som huleboer"}

Eksemplerne på bæredygtig levevis bliver flere og flere. Vi har brug for en kontrolleret overgang til bæredygtig livsstil for at undgå en lavere levestandard i fremtiden.

Fakta: Forskningen viser, at 2 tons $\mathrm{CO} 2$ pr. person om året vil udgøre en rimelig andel af udslippet af drivhusgasser. Dette betyder, at det materielle forbrug skal sættes kraftigt ned i de nordiske lande, som i øjeblikket udleder 6-9 tons $\mathrm{CO} 2$ pr. indbygger.

Udfordringer: Der er utopisk at tro, at vi kan fortsætte på den samme måde som nu, men alternativet - at leve bæredygtigt - er blevet fremstillet som et hårdt, kedeligt, besværligt og asketisk liv, hvor man ofrer sig og oplever en lavere grad af velfærd. Denne fremstilling gør det vanskeligt at fremme de bæredygtige måder at leve på og skabe accept og offentligt engagement. Det undergraver muligheden for at fremme produktdeling eller systemer med produkter i lukkede kredsløb, som kan 
reducere det samlede ressourceforbrug og miljøbelastningen forbundet med forbrug uden at have indflydelse på graden af velfærd.

Virkninger: Eksemplerne på bæredygtig levevis bliver flere og flere. Vi har brug for en kontrolleret overgang til bæredygtig livsstil for at undgå en lavere levestandard i fremtiden. Der er behov for en bedre forståelse for fordelene ved en bæredygtig livsstil, der giver høj velfærd for de enkelte borgere, samfundet og som samtidig er miljømæssigt bæredygtigt. Der er behov for at fremhæve bæredygtige levevis og understøtte for disse med argumenter for sundhed, høj livskvalitet og tilstrækkeligt materielt forbrug i modsætning til blot materiel overflod. Der er også behov for en bedre formidling af konsekvenserne af ikke at handle, og på en udramatisk og pragmatisk måde at vise, at tøven allerede nu medfører miljøproblemer (heldigvis endnu ikke synligt i de nordiske lande) og reducerer levestandarden i mange europæiske lande.

Der er behov for en bedre forståelse af den rolle som innovative, værdiskabende forretningsmodeller spiller i en grøn omstilling, fx udbud og efterspørgsel af tjenesteydelser i stedet for produkter (servicizing) Der er behov for både myndighedernes og virksomhedernes støtte til det voksende fællesskab af individer, kommuner og byer, som muliggør flere og flere bæredygtige måder at leve på gennem social innovation, fx samfund med lavt CO2-udslip og kollektivt forbrug.

\subsection{Myte 8: Mennesker bliver lykkeligere, hvis de tjener flere penge og forøger deres materielle forbrugsniveau}

I de nordiske lande er et stigende bruttonationalprodukt (BNP) forbundet med marginale forbedringer af velfærden. Derfor er der behov for nye indikatorer til at måle samfundsmæssige fremskridt.

Fakta: Der hersker i vores samfund en stærk tro på, at det at have flere penge eller eje flere materielle goder gør os lykkeligere og forøger vores velfærd. Forskning viser, at en stigning i BNP indtil et vist punkt er stærkt forbundet med vækst i den subjektive velfærd. Når en bestemt tærskel overskrides, vil stigninger i BNP blot medføre begrænsede og marginale forbedringer af velfærden.

Udfordring: Mennesker stræber efter højere indtægter og mere materielt forbrug $\mathrm{i}$ et forsøg på at forøge den personlige lykke, også selvom denne stræben nogle gange resulterer $\mathrm{i}$, at man må gå på kompromis med sundheden, fritiden og familie- og samfundslivet. På den anden side giver mennesker, som frivilligt vælger at arbejde og forbruge mindre, 
ofte udtryk for et stigende velfærdsniveau og en stigende tilfredshed med livet. De individuelle velfærdsniveauer påvirkes mere af den relative velstand der opleves i forhold til andre end det absolutte niveau af velstand. Visse undersøgelser peger på, at det er muligt at opnå højere velfærdsniveauer med lavere niveauer af materielt forbrug, når man har opnået et bestemt niveau af materiel standard.

Virkninger: Politikerne frygter at fremmedgøre borgerne med politiske tiltag, som skal håndtere forbrugsmønstre og forbrugsniveauer. Måske kan rammepolitik og tiltag som at fremme bæredygtig livsstil afdramatisere det nuværende fokus på materielt forbrug og give den samfundsmæssige debat et mere proaktivt og produktivt fokus på, hvordan menneskers livskvalitet kan forbedres. For at forstå og støtte menneskers drift i retning af at blive lykkeligere, er der behov for en langt mere nuanceret diskussion af vejene til lykke, end der i øjeblikket sker. Det er eksempelvis ikke tilstrækkeligt kun at høste fordelene af den teknologiske udvikling rent økonomisk, men også at søge lykke gennem meningsfyldte fritidsaktiviteter og personlig udvikling.

Vi har behov for at udvikle nye mål for samfundsmæssig velstand med henblik på at støtte og opfordre til bæredygtige måder at leve på. Et eksempel er de alternative indikatorer for BNP, som er udviklet af WAVES World Bank-programmet og Beyond Growth.

\subsection{Myte 9: Privat ejerskab af alle former for produkter er ønskeligt - deling er ikke}

Deleøkonomi og kollektivt forbrug af alle former for produkter er ved at komme igen. Beslutningstagerne kan hjælpe udviklingen på vej ved at reducere hindringerne for en deleøkonomi og en kollektiv økonomi og ved at støtte den nødvendige forskning i effekterne.

Fakta: Vores samfund er bygget op om idéen om at eje. Deleløsninger foretrækkes sjældent, når udgifterne til deling er højere end udgifterne til ejerskab - enten opgjort i penge eller den forbrugte tid til administration af deleløsningen.

Udfordringer: Mange mennesker bekymrer sig om det stigende antal produkter som optager plads i deres hjem og som kræver tid til vedligeholdelse. Produkter udskiftes hurtigere og hurtigere, og forbruget af billige produkter af en dårlig kvalitet er stigende.

Selv om vi ejer flere og flere produkter, er kollektivt forbrug ved at komme igen, fx i form af byttearrangementer, onlinesalg af genbrugsvarer, "udstyrsbiblioteker" og lejeordninger for biler og cykler i byerne. De 
nordiske lande har adskillige traditionelle deleordninger for produkter, såsom offentlige biblioteker og fælles vaskerier, der kan forbedres i kraft af nye innovative former for kollektivt forbrug af produkter.

Virkninger: Mange innovative nye virksomheder viser, at der er potentiale for at øge omfanget af deling og redistribution af eksisterende ressourcer og produkter. Genbrug af produkter modvirke de miljømæssige konsekvenser, som er forbundet med fremstillingen af nye produkter, og genvinding af mineraler og materialer fra produkter, bygninger og affald (urban mining) anses for at være en vigtig kilde til ressourcer i fremtiden. Deleøkonomi kan fremmes via formelle og uformelle initiativer med henblik på lån, bytte, vareudveksling og leje af produkter og tjenester i stedet for det individuelle ejerskab af produkter.

\subsection{Myte 10: Forbrugerpolitik er for kontroversiel til at blive accepteret af offentligheden}

Politik er aldrig neutral, men skaber sociale normer og værdier i samfundet. Beslutningstagerne skal skabe "mulighedernes politik" når det gælder omstilling til et bæredygtigt samfund ved at anvende og udnytte synergier fra en bred vifte af eksisterende og nye strategier og værktøjer.

Fakta: Politiske tiltag som fokuserer på bæredygtig forbrug har ikke så lang en historie som mange andre områder inden for miljøpolitikken. Forbrug opfattes ofte som en del af privatsfæren, og dermed som noget beslutningstagerne ikke skal blande sig i. Forbrugerne anses for at være suveræne, og de kan således selv foretage frie valg på markedet. Disse valg reflekterer deres præferencer. Derfor er beslutningstagerne ofte bekymrede for, at de forbrugerpolitiske tiltag er for kontroversielle, også selv om det offentlige har en stærk interesse i at påvirke forbrugsmønstrene.

Udfordringer: Der findes ikke politik, som ikke er værdiladet. Der eksisterer politiske tiltag på mange områder, der allerede nu indflydelse på vores individuelle livsstil og forbrug - vi er bare vant til dem, og derfor opleves de som "usynlige", fx love om spirituskørsel, sikkerhedsseler etc. Forbrugerlovgivning har vist sig effektiv, også i tilfælde, hvor et tiltag som udgangspunkt er blevet betragtet som værende for kontroversielt, fx rygeforbud, trængselsafgifter og udfasning af ineffektive elpærer.

Virkninger: På trods af en modvilje i forhold til at være interventionistisk eller paternalistisk er politik aldrig neutral, men skaber sociale normer og værdier i samfundet. Eksempelvis kan strenge mål for reduktion af drivhusgasser formidle alvoren i miljøspørgsmålet til befolkningen. 
Der findes adskillige strategier, som er kendt for at øge accepten af bæredygtige forbrugerpolitiske tiltag, $\mathrm{fx}$ at konstruere positive sociale normer med henblik på at skabe opbakning til stærkere politisk intervention, at give borgerne mulighed for at eksperimentere og få erfaringer med forslaget, at involvere borgerne i beslutningen, at opnå synlige positive effekter og at tilpasse holdningerne, når forslaget er implementeret og normaliseret. Således kan den måde, som en given politik formidles og implementeres på, i høj grad øge den offentlige accept - også når det gælder mere udfordrende adfærdsmønstre og forbudspolitik.

De nordiske beslutningstagere kan lade sig inspirere af John F. Kennedys beslutning om at sende en mand til månen. Da Kennedy først annoncerede idéen, blev den latterliggjort og kaldt "umulig". For at opnå det umulige skabte han en mulighedskultur, som bakkede op om hidtil ubegribelige og uforudsigelige teknologiske gennembrud. Indsatsen for at sende en mand til månen forudsatte systemiske og visionære forandringer, som krævede opbakning fra adskillige ministerier og sektorer, hvilket åbnede op for dybtliggende kulturelle værdier med henblik på at skabe "mulighedernes politik". 


\section{Hovederfaringer med vidensformidling}

En af de centrale forhindringer i forhold til en evidensbaseret politikformulering inden for bæredygtigt forbrug er de vedvarende misforståelser, forenklinger og generaliseringer, når det gælder forbrugeradfærd. I denne tekst kalder vi disse for myter. Noget af kompleksiteten skyldes, at alle myter indeholder et element af sandhed. Derfor er det afgørende at finde og præsentere den tilgængelige evidens på en objektiv og afbalanceret måde. Et andet problem er at forskning i forbrugeradfærd i høj grad er kompleks og kan være vanskelig at udnytte på det politiske område, især fordi de fleste beslutningstagere, som udarbejder politik for bæredygtigt forbrug, har en baggrund som økonomer, ingeniører, jurister eller har naturvidenskabelige uddannelser, mens beslutningstagere med en baggrund inden for adfærdsvidenskaberne er underrepræsenterede. Som følge af denne strukturelle fastlåsthed, er anvendelsen af evidens fra adfærdsvidenskaberne utilstrækkelig.

Denne undersøgelse har vovet sig ind i den omfattende samling af viden om forbrugeradfærd, og således indsamlet og præsenteret evidens for de førnævnte misforståelser. Desuden har undersøgelsen identificeret de forhindringer, som er forbundet med den nuværende vidensdeling og har skitseret de bedste midler med henblik på at gøre viden, deling og udveksling mere tilgængelig. Disse indsigter blev opnået via interviews med nordiske beslutningstagere og kan bidrage til at reducere forhindringerne i forhold til udvikling og implementering af en politik for bæredygtigt forbrug og livsstil.

\subsection{Sådan bruges forskningsresultater i politikformuleringen}

Tiden er den primære forhindring for de nordiske beslutningstagere, når det gælder udnyttelsen af forskningsresultaterne. Denne situation tyder på, at der er et behov for forenklet information, som er mere egnet med henblik på politikformulering. Forskere og beslutningstagere har ofte ret forskellige vidensinteresser. Mens forskere stræber efter at udfordre de eksisterende 
synspunkter og skabe ny viden, er beslutningstagerne interesseret i viden, som er let at bruge og som tilbyder gennemsigtige løsninger.

Politikformulering er altså ikke blot en proces, som handler om at anvende forskningen, men en kompleks politisk proces. Derfor skal forskningen være overbevisende, ikke kun for embedsmændene, men også for politikerne og deres vælgere. Dette er ofte blevet nævnt som et af de centrale områder, hvor forskningen ikke lever op til forventningerne. Flere af de interviewede understregede, at manglen på samfundsmæssig og politisk konsensus ofte har vist sig at være en hindring med henblik på at implementere ny viden.

De fleste af de interviewede bemærkede, at jura og økonomi er de to forskningsdiscipliner, som har opnået en etableret anvendelse i politikformuleringen. Inden for miljøpolitikken gør man desuden ofte brug af natur- og ingeniørvidenskab, som også anses for at være vigtige når det gælder udvikling af forbrugerpolitiske tiltag for et bæredygtigt forbrug. De største problemer med hensyn til integration af viden blev fundet inden for socialvidenskaberne, som ofte ikke er kumulative eller kontekstuafhængige på samme måde som naturvidenskaberne er. Forbrugeradfærd består af forskellige former for adfærd, som finder sted i forskellige kontekster, så der er ingen overordnet teori eller eksakte love at trække på.

\subsection{Tilgængeligheden af tilstrækkelig forskning med henblik på politikformulering inden for bæredygtigt forbrug}

Mange af de interviewede understregede behovet for mere tværfaglig forskning, især med henblik på, hvordan forbrugernes adfærd kan ændres og hvilken betydning den offentlige politik har for forbruget i samfundet, fx når det gælder forholdet mellem forbrug, lykke og velfærd.

De største videns gab, som er identificeret af de nordiske beslutningstagere, kan opsummeres på følgende måde:

- Utilstrækkelighed: Forskningen er utilstrækkelig, modstridende og forbrugeradfærden er ikke fuldt ud forstået.

- Kompleksitet: Information bliver ikke indsamlet og præsenteret i en form som er let at forstå, hvilket medfører at den bliver usynlig og ikke bliver anvendt af beslutningstagerne. 
- Mangel på umiddelbar adgang: Mange af de interviewede gav udtryk for, at det er vanskeligt umiddelbart at få adgang til den nødvendige information, når der er behov for den.

- Mangel på anvendt forskning og politiske vurderinger: Adskillige af de interviewede understregede, at der er begrænset evidens til rådighed om effektiviteten af de politiske tiltag. Dette skyldes delvist en mangel på politisk kontrol og evaluering, men også en mangel på anerkendte metoder til at evaluere effektiviteten af politiske instrumenter og tiltag.

- Mangel på landespecifik forskning: Dette er et større problem for nogle lande end for andre. Det er indlysende, at konteksten har indflydelse på effektiviteten af de politiske tiltag, og der er behov for undersøgelser, som kan teste hvor de politiske tiltag kan anvendes $\mathrm{i}$ forskellige kontekster.

- Mangel på dedikeret forskning: Eftersom forbrugerpolitik indenfor bæredygtigt forbrug og livsstil er et forholdsvist nyt politikområde, er det vanskeligt at identificere hvilken forskning der er relevant, og hvordan den eksisterende forskning skal kombineres med henblik på bedst muligt at opfylde behovene i politikformuleringen. Jo større et givent samfundsmæssigt problem er, desto større er behovet for at samarbejde med forskningen inden for flere discipliner, selv om forskningsfinansieringen ikke altid støtter de tværfaglige behov for forskning inden for bæredygtigt forbrug.

\subsection{Evidensbaseret politik inden for bæredygtigt forbrug}

De fleste af de interviewede gav udtryk for, at der er en utilstrækkelig viden om evidensbaseret politikformulering, især når det gælder undersøgelser af politisk intervention. De lagde vægt på behovet for flere effektstudier, således at politikken kan baseres på videnskabelig evidens.

De områder, hvor der er den største mangel på evidens er de økonomiske virkninger samt effektive måder at skabe ændringer i forbrugernes adfærd. Ofte er årsagen til at politiske tiltag ikke bliver testet, kontrolleret eller evalueret mangel på tid og penge, og resultaterne af de få tilgængelige undersøgelser bliver dermed ikke brugt. Alligevel er evidensbaseringen stærkere på nogle områder end på andre, fx findes der temmelig meget evidens om offentlighedens anerkendelse af og tillid til Svanemærket, men knap så meget i forhold til andre instrumenter. 
Desuden mente nogle af de interviewede, at den manglende evidensbasering ikke umiddelbart er det største problem. De fremhævede derimod forskellige politikkers rolle i formuleringen af en forbrugerpolitik for bæredygtigt forbrug og livsstil samt modstandere af en bæredygtig forbrugerpolitik, som eksempelvis lobbyister.

\subsection{Hindringer i forhold til anvendelsen af viden og idéer med henblik på at overvinde dem}

De nordiske interviewpersoner har identificeret to hovedkategorier af hindringer: Ideologiske/politiske og praktiske hindringer. De understregede vigtigheden af politikkens rolle i politikformuleringen, idet forskellige ministerier, politiske partier og myndigheder har forskellige prioriteter, fx konsekvenser for jobskabelsen eller skatteindtægterne. De primære hindringer udspringer dog af en kombination af de politiske faktorer og den måde, hvorpå politikken gennemføres i praksis. De nordiske beslutningstagere har desuden foreslået, at en forbedring af vidensbasen, og især udnyttelsen af viden i den politiske forhandlingsproces, måske kan hjælpe med at overvinde de ideologiske og praktiske problemer. De havde også nogle idéer til, hvordan hindringerne kan overvindes.

Der blev fremført adskillige argumenter for mere samarbejde mellem ministerierne. Dette blev anset for at være meget vigtigt, idet forskellige politiske instrumenter ofte administreres af forskellige ministerier, og det er i en sådan situation vanskeligt at udarbejde en effektiv kombination af politiske tiltag. Visse aspekter af forbruget (fx bolig) er antagelig i højere grad omfattet af de eksisterende administrative strukturer end andre. Manglen på politisk koordinering og eksistensen af modsatrettede kræfter gør det vanskeligt at tage beslutninger.

Når det gælder politisk lederskab, blev det foreslået, at forskerne skal kommunikere mere direkte til politikerne og offentligheden. Embedsmænd kan ikke umiddelbart gå forrest i den politiske proces, men får deres mandat til at udarbejde politik af politikerne. På den anden side kan forskerne muligvis sætte fokus på begrænsningerne i forbrugernes suverænitet og den kendsgerning, at borgerne rent faktisk sætter pris på politisk lederskab. Alligevel bemærkede nogle af de interviewede, at de resultater, som forskerne kommunikerer ud til offentligheden ofte er modstridende, og dermed ikke tjener noget formål med henblik på at fremme politisk lederskab når det gælder bæredygtigt forbrug. 
De webbaserede seminarer som blev gennemført som en del af denne undersøgelse, blev særdeles positivt modtaget af deltagerne og kan således udgøre en brugbar model for den fremtidige dialog mellem forskere, beslutningstagere og andre interessenter. Deltagerne roste den "innovative måde at udveksle idéer på", muligheden for at få kontakt med nye og gamle kolleger, muligheden for at opdatere deres viden og at få de endelige resultater af undersøgelsen, som de har bidraget til via webbaserede seminarer. Dette kan muligvis øge villigheden til at bruge forskningsresultaterne.

Denne undersøgelse har bekræftet, at en stor del af den eksisterende samling af viden om forbrugerpolitik er kompleks, nuanceret og kontekstafhængig, hvilket tyder på et behov for nye institutioner for vidensmægling.

- Et center for vidensmægling, eksempelvis under Nordisk Ministerråd, som skal identificere relevante undersøgelser fra pålidelige kilder, vurdere kvaliteten af den videnskabelige information og formidle den nyeste viden til de nationale regeringer.

- Et "konsensuspanel" for forskere med henblik på at samle og præsentere hovedkonklusionerne fra forbrugsforskningen - på samme måde som FN's Klimapanel (IPCC) har gjort.

- En tænketank eller et forum med henblik på at etablerer kontakt mellem forskersamfundet og forbrugerorganisationerne. Et forum af denne type kan baseres på de solidariske og socialdemokratiske værdier, som er relevante for den såkaldte nordiske model.

Forummet vil udforske et globalt perspektiv, og ikke blot diskutere konsekvenserne af forbruget for de nordiske forbrugere, men også for forbrugere og lande uden for Nordens grænser.

De praktiske forslag til præsentation af forskningsresultater bestod blandt andet af efterlysninger af simple forklaringer på komplekse spørgsmål i et tilgængeligt format, tegninger og diagrammer, gode resuméer på 2-4 sider og tydelige konklusioner. Forskningsresultaterne bør præsenteres kortfattet og med overbevisning, ligesom lobbyisterne i Europa-Kommissionen gør. 



\section{Parametre for undersøgelsen}

\subsection{Formål med undersøgelsen}

De specifikke formål med denne undersøgelse er at forbedre de nordiske beslutningstageres viden om:

- Centrale myter om forbrugeradfærd som hindrer en effektiv politikformulering når det gælder bæredygtigt forbrug.

- Centrale erfaringer fra den tværfaglige forskning om forbrugeradfærd og forbrug.

- Betydningen af den opnåede nye viden med henblik på politiske virkninger.

Denne undersøgelse af vidensmægling strakte sig over et år og bestod af 4 trin:

Trin 1: En desktop-undersøgelse, som indeholdt en meta-analyse af litteraturen om den eksisterende samling af viden om hver myte i overensstemmelse med den følgende struktur: 1) mytens oprindelse; 2) konsekvenser for samfundet, forbrugsmønstre og forbrugsniveauer, aktører og politiske tiltag; 3) argumenter, evidens og data som kan tilbagevise hver myte; 4) betydningen for de eksisterende og fremtidige politiske strategier.

Trin 2: Den empiriske undersøgelse bestod af indsamling af data via semistrukturerede interview med 22 nordiske beslutningstagere og eksperter om myter om forbrugeradfærd og myternes betydning for politikformuleringen når det gælder fremme af bæredygtigt forbrug. Der blev etableret 2 fokusgrupper med 10 forskere inden for bæredygtighed og 8 borgere (medlemmer af Swedish Association of Sustainability Psychology).

Trin 3: Analyse og syntese kombinerede den akademiske forskning med beslutningstagernes erfaringer fra det virkelige liv inden for bæredygtigt forbrug. Dette giver mulighed for en samlet evaluering af de spørgsmål, som er relevante for politikformuleringen når det gælder bæredygtigt forbrug.

Trin 4: Formidlingen og gennemgangen af resultaterne omfattede feedback fra målgruppen - primært nordiske beslutningstagere - via et webbaserede seminar. Der blev desuden arrangeret et andet webbase- 
rede seminar for at undersøge tilgængeligheden af viden og resultater. Deltagerne var en gruppe af forskere og praktikere inden for bæredygtig forbrugerpolitik, eksperter fra det civile samfund og studerende fra Europa og USA. I alt deltog 68 personer i de webbaserede seminarier. Det andet seminarier resulterede i supplerende feedback om nogle af de mere nuancerede og kontroversielle spørgsmål og tilføjede styrke og validitet til undersøgelsens endelige resultater.

\subsection{Resultaterne af undersøgelsen}

- Den endelige rapport på svensk og engelsk: http://dx.doi.org/10.6027/TN2013-552 http://dx.doi.org/10.6027/TN2013-553

- Policy brief på engelsk

- Blog på engelsk http://sustainabilitymyths.blogspot.se/

- Optagelse af det webbaserede seminar: https://connect.sunet.se/p6xwhdd4evj/ 


\section{Information om projektet}

\section{Koordinator}

Internationella miljöinstitutet

Lunds universitet

P.O. Box 196 Tegnersplatsen 4,

SE- 22100 Lund, Sverige

http://www.iiiee.lu.se/Tlf.: +46 462220250

Fax: +46 462220230

Oksana Mont, projektleder: oksana.mont@iiiee.lu.se

\section{Konsortium}

Oksana Mont, Lunds universitet, Sverige

Kate Power, Copenhagen Resource Institute, Danmark

Eva Heiskanen, Konsumentforskningscentralen, Finland

Helka Kuusi, Konsumentforskningscentralen, Finland

\section{Kontaktperson i NMR}

Camilla Sederholm + 358400930886

E-mail: camilla.sederholm@miljo.fi

www.norden.org/hkp

\section{Varighed}

15. maj 2012 - 15. april 2013

\section{Finansiering}

Nordisk Ministerråd

Bidrag fra NMR: 330.000 DKK

\section{Netsteder}

http://sustainabilitymyths.blogspot.se/ Den endelige rapport over undersøgelsen:

http://dx.doi.org/10.6027/TN2013-567 
Ved Stranden 18

DK-1061 Copenhagen K

www.norden.org

Nordisk Policy-sammendrag

På trods af 20 års politisk indsats for en bæredygtigt livsstil fortsætter det materielle forbrug med at stige i Norden, hvor det er en ambition at være førende i bæredygtig samfundsudvikling. Det står klart, at den nuværende forbrugerpolitik ikke er så effektiv, som den kan være.

Dette policy papir giver en række grunde til dette, lige fra forbrugernes selvbestemmelsesret, manglen på politiske instrumenter og til manglen på politisk mod til at involvere sig i forbrugerspørgsmål. Der eksisterer især i de politiske cirkeler nogle vedvarende misforståelser - myter om forbrugeradfærd og bæredygtigt forbrug. Dette policy-sammendrag beskriver 10 myter om omstilling til en bæredygtig livsstil, der indtil nu har fastholdt beslutningstagerne i et fokus på teknologisk innovation og produkteffektivitet. 10 myter der indtil nu har forhindret at social innovation, nye alternative modeller for værdiskabelse, og at normer for et rimeligt forbrug har fået den nødvendige opmærksomhed.
TemaNord 2013:567

ISBN 978-92-893-2609-4

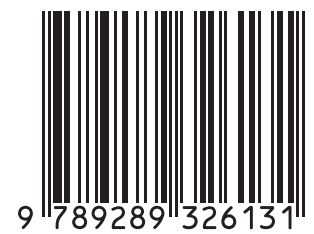

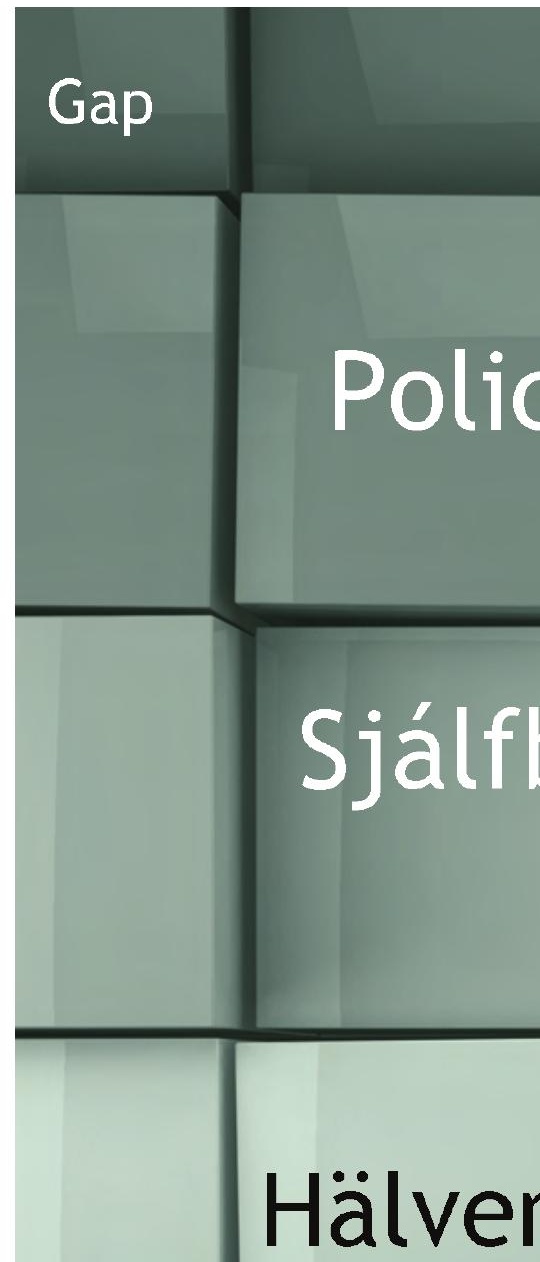

Yfirs 